\title{
The Meaning of Gong Waning Music Spirituality In The Community Death Ritual of Sikka District
}

\author{
Katharina Kojaing \\ ${ }^{1}$ Faculty of Education and Teacher Training, Univesitas Katolik Widya Mandira \\ Kupang, Indonesia \\ chaterine21@hotmail.com
}

\begin{abstract}
Gong Waning is an ethnic instrument from Sikka Regency, Flores Island of NTT, which is played by beating. However, the presence of Gong Waning's music in the ritual of death was not intended for all those who died in the village only limited to a certain age of 70 years and above. The method used is qualitative with an ethnographic approach. The results showed that; first; the meaning of the music spirituality of Gong Waning in the traditional ritual of the death of the Hewokloang people is a joy. Second: Gong Waning's music is only played for people who die at the age of 70 years and above is a symbol of LeroLebek (sunset), which is identical to the old age or resting phase. The 70-year standard is taken from the myth of the Hewokloang people about Seu Lape Pitu Lape Walu City means seven levels of the upper world and eight cities, which means heaven. Death which is paraded with music and dance in the Hewokloang tradition is identified with the death of the king.
\end{abstract}

Keywords: The Meaning of Spirituality, Gong Waning, Death Rituals.

\section{INTRODUCTION}

Gong Waning is a musical instrument from the Sikka regency that is played by being beaten, and is a variety of elements of local wisdom that embody the life of the Hewokloang people. This instrument consists of six gongs and two drums (Waning) and a bamboo stick (Lettar), which have very strong sound frequencies and the rhythm played varies, from fast tempo (allegretto) to very fast tempo (allegro). In the Sikka District community in general, the position of this instrument is as a dance accompaniment with a theme of excitement, so that it is often presented in a variety of traditional parties, both marriages, religious rituals, welcoming honored guests, as well as other types of entertainment parties. However, one thing that is unique and Interestingly, this Gong Waning instrument was presented in a traditional ritual of death with a theme of grief by the Hewokloang community in Sikka district. 
The Hewokloang area is located in the village of Hewokloang, District of Hewokloang, Sikka Regency on Flores Island, NTT Province. The Hewokloang people live a legacy of local traditions that are somewhat unique compared to other regions in Sikka Regency in general, namely presenting Gong Waning music in their customary rituals of death. But the presence of Gong Waning's music in the death ritual is not for all those who die in the Hewokloang area but only limited by a few tribes. There are 13 tribes (Lepo) inhabiting the village of Hewokloang, and only seven tribes (Lepo) can ritualize death with the accompaniment of Gong Waning's music because the 7 tribes are still descended from the king's descendants. More specifically, the deaths of Hewokloang people from the 7 tribes were not all ritualized by the music of Gong Waning, but were only limited to the age of 70 years and above.

In general, if there is a death in the Sikka District community, all family members mourn even some families mourn for months. But this fact is inversely proportional to the situation experienced by the Hewokloang people. Based on the writer's observation in 2016 on the death of the late Thomas Tara (74 years), the Hewokloang community presented Gong Waning music in the death ritual and celebrated royally like an entertainment party. This tradition is still inherited and preserved for generations to this day.

Gong Waning's music was played all day long until the body was buried. The length of the existence of a corpse in a funeral home ranges from 3 to 5 days depending on the family's agreement, which waits for all biological family members to attend the ritual. If there are still biological children who are still overseas, then the body cannot be buried and must wait until all the children are present.

As long as the body remains in the funeral home, Gong Waning's music continues to play. Outside the tent, some people were dancing to the music of Gong Waning, while inside the house (where the body was laid) some families were seen crying and lamenting the death of the deceased. When they finished crying and wailing, some people went out to the mourning tent and got involved with playing music and dancing together.

The characteristics of Gong Waning's music (tempo and fast rhythm) can dissolve all feelings of grief and sadness, so that the cry is not heard, especially from the family left behind. This unique pattern of celebration of the death tradition has not been found anywhere else in Sikka district. _ If there is another area in Sikka Regency, it is also the people of Hewokloang descent who have long migrated and settled in the area out by other cultural communities in Indonesia.

The death ritual for the Hewokloang people "seems" to be an "exhilarating" celebration that should be enlivened by the sound of Gong Waning's music. Seeing the meaning of this instrument symbolically expresses excitement, it does not seem so relevant if it is used in the ritual of death, which is generally themed grief

Then, what is the meaning of the spirituality of Gong Waning's music in the customary ritual of death for the Hewokloang people, and why Gong Waning's music is only intended for people who die at the age of 70 years and above, in detail explained in this discussion.

\section{METHOD}

The method used in this study is a qualitative ethnographic approach, in which the researcher lives and experiences directly every event and event in this case ritual and death which are celebrated by the Hewokloang community. Also, additional information was obtained through 
interviews and discussions with several speakers and some documentation in the form of photos and videos.

\section{RESULTS AND DISCUSSION}

\subsection{Spirituality of Gong Waning Music}

The study of music needs to emphasize the text and context. Text is a study of music in terms of musical elements or intra-musical and aesthetic aspects, while the context is the linkage of extra-musical studies, one of which is the atmosphere, namely the conditions formed by the community supporting the music. In other words connecting music with the cosmos, namely the natural environment and other elements of the cosmos [1].

Gong Waning, philosophically, based on the sound, Gong can be interpreted as "echo" or "echo". While "Waning" is often identified with the musical instrument "drum" or "drum". Based on the type of musical instrument, Gong Waning is interpreted as symbolic of "excitement". The presence of this musical instrument is very striking to provide a color of excitement in music playing, especially in Sikka Regency.

So, in the context of the Sikka Regency community, Gong Waning is interpreted symbolically as an "Echo of Joy". In the Sikka community ritual, this musical instrument has a psychospiritual element, which means it has a strong influence on the psychological atmosphere of people's spiritual life. Generally, the presence of Gong Waning brought a festive atmosphere to each ceremony.

Likewise in death, Gong Waning's music is not necessarily presented just like that, but rather contains certain elements of meaning that the heir community intends to convey in this case the Hewokloang community. According to [2], the delivery of a story with song or recitative music in various ceremonies and dances, is the same as speaking directly to participants. Music cannot be separated from talking, and playing music is talking.

The presence of Gong Waning ethnic music in the ritual of death with a variety of tones, rhythm patterns, and fast tempo, even dances, are presented to the stage of death in an atmosphere of mourning. In the context of death, Gong Waning's music both internally and externally are both presented in the ritual of the death of the Hewokloang people.

While in the external aspect, there are types of musical sounds that were born from the music group namely the sound of Gong, the sound of drums (Waning), and the sound of a bamboo punch (Letar). On the external side too, there are several types of rhythmic patterns, tempo and tone played, to create a festive ceremony.

So music with major mode, fast tempo, high notes, flowing rhythm, constant harmony with medium volume, can evoke a happy mood, is true as it happens and experienced by the Hewokloang people [3].

\subsection{Gong Waning music and social status}

The tradition of the death ritual performed by the Hewokloang community is very different from the death tradition of the Sikka community in general. Understanding the meaning of death which is synonymous with grief, tears of sorrow, mourning, and lamentations that have long-lived and adhered to the Sikka people generally, seemed to be worth nothing. Gong Waning's musical presence dispelled this understanding. For the Hewokloang people (who are members of the seven 
tribes), the presence of Gong Waning's music in the ritual of death is a must. This is because of their belief that death is the beginning of a new life in a new world, death is a change of residence from the world of Ata Moret (living people) to the world of Ata Mate or Nitu (the world of the dead.

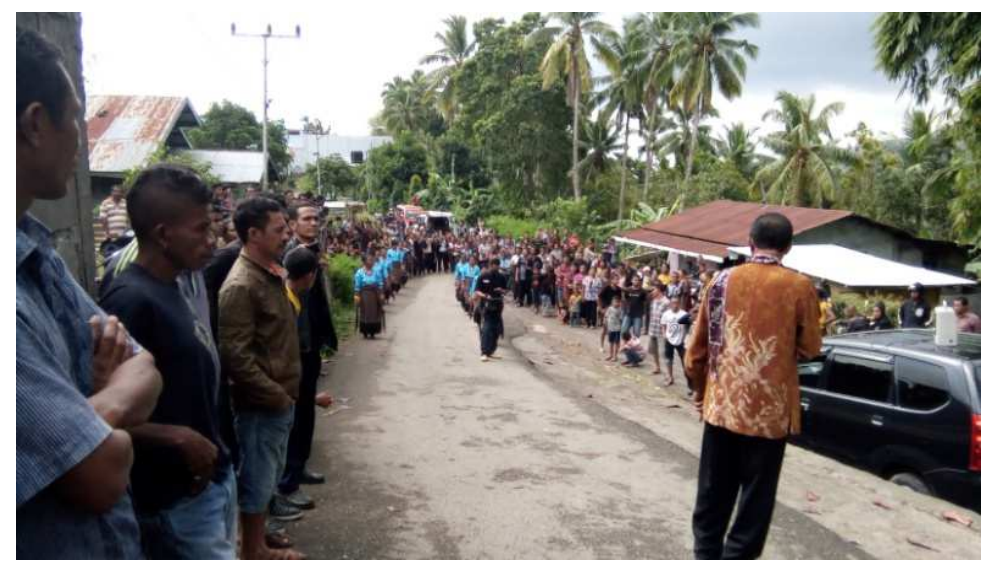

Image 1. Preparation for picking up dead body. Thomas Tara (74) in Gong Waning's dance and music Source: Personal Documen

The management of social life that is built by the community because there is a class that limits their space and lifestyle. This differentiation is evident in the tradition of their death. Even though they are in a small village area with a cultural pattern that is adopted as a whole it is almost the same, but specifically in death, they are limited by certain classes or strata.

Lepo factors or tribes that influence these differences. Of the 13 Lepos in Hewokloang, there are only 7 Lepos that can ritualize death with the accompaniment of Gong Waning music and festive dances. This is because the 7 Lepos came from the descendants of the king/nobility, descendants of Ata MenumBalik (rich people). While the other 6 Lepos should not be ritualized by festive parties and musical accompaniment of Gong Waning, although from economic factors they are classified as very capable because, in terms of family offspring, they are not included in the royal lineage[3].

The seven Lepos in Hewokloang always reveal the unique nuance of the death ritual tradition compared to the Sikka community in general. Although some villages carry out similar death ritual traditions that present the music of Gong Waning in their deaths, but from the family tree, they are Hewokloang people who are still included in the same lineage (of the seven Lepos), who wander and settle in the village other.

Gong Waning seems to have been embedded in the tradition of their lives, so it is very strange if there is the death of parents from Lepo and ritualized without any musical accompaniment[4]. Gong Waning's musical attachment has been integrated into their mind, mindset and life management, and this has been going on for a long time and is regenerative.

The death ritual of elderly parents (more than 70 years old) must be accompanied by Gong Waning music and festive dances because it is jerked with the death of a king. Then this will be 
unethical, if it is buried without the accompaniment of Gong Waning music and festive dances as happened at the death of the king before. As revealed by FeriRebing in the death of the late Thomas Tara (74 years) said thus:

Even though it must be compartmentalized in terms of age, for the Hewokloang people - the specifications of the seven Lepos, the celebration of the death party accompanied by the music of Gong Waning and festive dance performances only apply to people who bear the title of king or hero of defending the truth[5]. Ritual procession in the death of Thomas Tara, identified with the procession of a king's death ritual. Therefore, in the customary management of the Hewokloang community, the deceased who is ushered in a music and dance procession is a highly respected person, a person who has a higher position in the community[6].

\subsection{Music Gong Waning and 70 Years of Age}

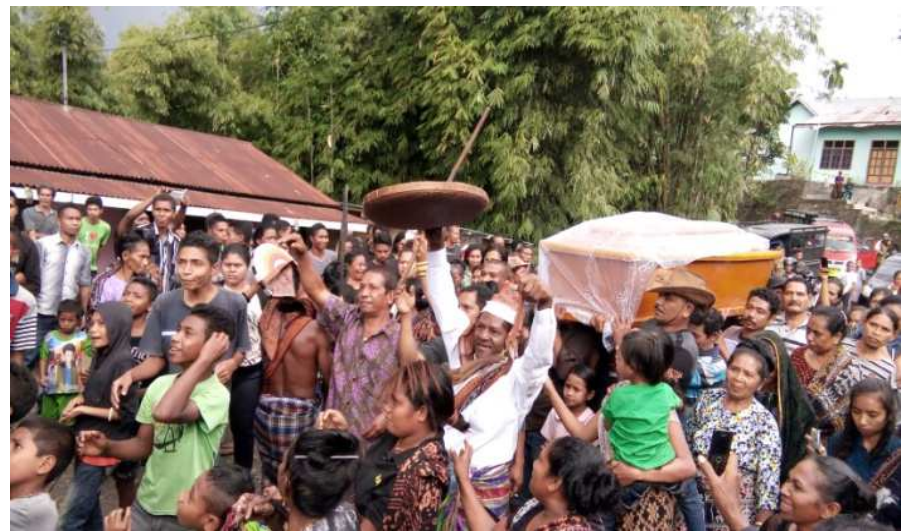

The death of a person who is 70 years old is a number that is classified as old in terms of the age of human life. Humans have walked the path of their lives from infants through the process of living in a vulnerable time that is so long, from number 1 to number $70_{-}$if stretched in a matter of years. That is, he has gone through various life processes with all the joys and sorrows and various other life experiences.

According to Hewokloang mythology, the age of human life is analogous to the rotation of the sun (Lero), from sunrise (LeroBekor) to sunset (LeroLebek). Deaths of people under the age of 70 and below are classified in LeroBekor (sunrise), while those aged 70 years and over are included in the LeroLebek (sunset) category. Therefore, in the ritual burial procession must be adjusted to the age of the person who died.

People who die at a young age (under 70 years) are called MatenMegun, meaning death that is still loved. Therefore, burial rituals are held in the morning or afternoon and no Gong Waning music and festive dances should be played. His departure must be accompanied by crying, lamentation, mourning, and deep sorrow.

This is because the family still wants its presence with the family in building and continuing the Lepo (tribe) in Hewokloang. So in MatenMegun the burial ritual is usually done in the morning ranging from 9:00 am to 12:00 to follow the direction of motion/rotation of the sun.

In contrast to parents, if the dead are parents (more than 70 years), then the death is referred to as Mate Ata Blupur (death of parents). Mate Ata Blupur in the belief of the Hewokloang community is included in the LeroLebek (sunset) classification, meaning that it falls into the category of old age. 
Burial rites in the death of Mate AtatBlupur must be accompanied by music Gong Waning and festive dances. Burial processions must also be carried out in the afternoon following the direction of the sun's motion. As in the death of the late Thomas Tara (74 years) of the tribe or LepoBaoBlutuk too, his burial was carried out at $5 \mathrm{pm}$ with the accompaniment of Gong Waning music and a merry dance.

The relevance of the mythical meaning of the number 70 in death is, the basic beliefs of Sikka Regency people about death, generally lies in the number Seven (Pitu) and the number Eight (Walu) which in Sikka is called SeuLapePituLapeWalu City. It means "seven layers of heaven, eight parts city". In the sense that SeuLapePituLapeWalu City is another name for heaven.

According to [3], the two numbers (7 and 8) remind us the levels of above the world (sky) and the underworld, namely Pi PituLapeWalu (seven levels, eight parts). The eight parts are in the form of the earth along with the seven levels below, while the other seven levels are above the earth. Pi PituLapeWalu or SeuLapePitu, LapeWalu City (the world of seven levels of eight parts), or in other terms is often called the seventh heaven Most people often refer to the term "above the sky there is still a sky".

Death of parents in their 70s and above is an encouraging death. This is because besides he has completed his life's duty in the world, it is also the credo of the people's myth that at the age of 70 years it is possible to go to SeuLapePitu, LapeWalu City (heaven). Therefore (apart from a background of royal family descent) the death of 70-year-old parents in the Hewokloang community must be celebrated with the accompaniment of Gong Waning music and dance, as well as spiritual contributions in the form of prayer intentions from surviving families.

In research in Africa [7], revealed that any music in Africa, can support mood in acting or provide a channel for feeling cathartic. The formal part of the ceremony is often followed by music and dance which provide a space for emotional expression to be felt[8].

Gong Waning's musical accompaniment in the ritual of death can dissolve all feelings of sorrow into joy and joy. The form of social psychology's expression of music is shown through the lively dances of mourners, who are directly involved in the ritual of death[9][10].

Emotional expressions of the feelings of the community show that, in many societies, music is not only enjoyed for itself but is an integral part of culture. Music accompanies human activities from birth to death. Two of the various roles that music plays in human life are as the accompaniment of dance and communication media [11].

\section{CONCLUSION}

From these results it can be concluded that; the meaning of Gong Waning's musical spirituality in the traditional rituals of Hewokloang's death is a joy. The expression of joy is expressed through Gong Waning's dance and music with various flowing rhythms (Badu Blaba, Todu, and Glebak), and in fast tempo (Allegro_Allegretto), as well as moderate sound volume, concerning intra-musicals this indicates a form of excitement. Gong Waning's music is only intended for people who die at the age of 70 years and above is a symbol of LeroLebek (sunset), and (possibly) can go to SeuLapePituLapeWalu City (heaven), because the symbol of LeroLebek has the meaning of the evening. and the sun will set, so that the age of 70 years is identical to the old age or the resting phase. 


\section{REFERENCES}

[1] Nakagawa. Shin. Musik dan Kosmos Sebuah Pengantar Etnomusikologi. Jakarta: Yayasan Obor Indonesia. 2000.

[2]Hargreaves. David. J. dan Adrian C. North. (Eds.), The Social Psychology of Music. Oxford: University Press. 1997.

[3] Arndt. Paul. Agama Orang Ngadha: Dewa, Roh-Roh, Manusia, dan Dunia. Seri Etnologi Candraditya Vol. 1(6.) Puslit Candraditya. 2005.

[4] Arndt. Paul. Falsafah dan Aktivitas Hidup Manusia di Kepulauan Solor. Seri Etnologi No. 5.(1). 2003

[5] Nyoman, I Cau Arsana, G. R. Lono L. Simatupang, R. M. Soedarsono, I Wayan. "Kosmologis Tetabuhan dalam Upacara Ngaben". Resital: Journal Performing of Arts Vol 15 No.1.2014.

[6] Banoe, Pono. Kamus Musik. Yogyakarta: Kanisius. 2003.

[7] Riyanto, Armada, Ohoitimur,Johanes, Mulyaton, C. B., Madung, Otto Gusti. Kearifan LokalPancasila Butir-Butir Filsafat Keindonesiaan. Yogyakarta:Kanisius. 2015.

[8] Barthes, Roland. 1983. Mythologies: EdisiRevisi. Yogyakarta: KreasiWacana.

[9] Sugiono, Dendy. 2008. Kamus Besar Bahasa Indonesia, Pusat Bahasa Departemen Pendidikan Nasional Jakarta: Pusat Bahasa.

[10] Djohan, 2010. ResponsEmosiMusikal. Bandung: LubukAgung.

[11] Rumengan, Perry. 2011. Musik Vokal Etnik Minahasa Teori, Gramatika, dan Estetika, Yogyakarta:Program Pasacasarjana ISI Yogyakarta 